\title{
Modulation of Transmission during Trains at a Cerebellar Synapse
}

\author{
Anatol C. Kreitzer and Wade G. Regehr \\ Department of Neurobiology, Harvard Medical School, Boston, Massachusetts 02115
}

\begin{abstract}
Activity-dependent processes dynamically regulate synapses on the time scale of milliseconds to seconds. Here, we examine the factors governing synaptic strength during repetitive stimulation, both in control conditions and during presynaptic inhibition. Field recordings of presynaptic volleys, optical measurements of presynaptic calcium, and voltage-clamp recordings of postsynaptic currents were used to examine parallel fiber to Purkinje cell synapses in cerebellar brain slices at $34^{\circ} \mathrm{C}$. In control conditions, regular stimulus trains $(1-50 \mathrm{~Hz})$ evoked up to a $250 \%$ peak synaptic enhancement, whereas during irregular stimulation, a threefold variability in EPSC amplitude was observed. When initial EPSC amplitudes were reduced by $50 \%$, either by lowering external calcium or by activating adenosine $A_{1}$ or $G A B A_{B}$ receptors, the peak enhancement during regular trains was $500 \%$, and synaptic variability during irregular trains was nearly sixfold. By contrast, changes in fiber excitability and calcium influx per pulse were small during trains. Presynaptic
\end{abstract}

calcium measurements indicated that by pulse 10 , stimulusevoked calcium influx had increased by $\sim 15 \%$, which on the basis of the measured relationship between calcium influx and release corresponds to an EPSC enhancement of $50 \%$. This enhancement was the same in all experimental conditions, even in the presence of $N^{6}$-cyclopentyladenosine or baclofen, suggesting that repetitive stimulation does not relieve the G-protein inhibition of calcium channels by these modulators. Therefore, for our experimental conditions, changes in synaptic strength during trains are primarily attributable to residual calcium $\left(\mathrm{Ca}_{\text {res }}\right)$-dependent short-term plasticities, and the actions of neuromodulators during repetitive stimulation result from their inhibition of initial calcium influx and the resulting effects on $\mathrm{Ca}_{\text {res }}$ and calcium-driven processes.

Key words: $G A B A_{B}$ receptor; adenosine $A_{1}$ receptor; presynaptic inhibition; short-term plasticity; residual calcium; cerebellar granule cell; cerebellar Purkinje cell
Neurons in vivo fire both regularly and irregularly, often at rates of up to several hundred Hertz. The amount of neurotransmitter released in response to an action potential depends on the type of synapse, its history of activity, and the presence of neuromodulators (Magleby, 1987; Zucker, 1989; Wu and Saggau, 1997; Zucker, 1999). High-frequency stimulation enhances some synapses, depresses others, and can often produce transient enhancement followed by depression (Feng, 1941; Liley and North, 1953; Del Castillo and Katz, 1954). Furthermore, complex activity patterns similar to those observed in vivo can lead to highly variable synaptic responses (Tsodyks and Markram, 1997; Varela et al., 1997; Dobrunz and Stevens, 1999), and this variability is thought to play an important role in nervous system function (Buonomano and Merzenich, 1995; Abbott et al., 1997; Lisman, 1997; Tsodyks and Markram, 1997).

Many temporally overlapping processes could contribute to changes in synaptic strength during repetitive activity. (1) Changes in the presynaptic action potential waveform could alter the activation of voltage-dependent calcium channels driving neurotransmitter release (Dunlap and Fischbach, 1978; Klein and Kandel, 1980; Augustine, 1990; Sabatini and Regehr, 1997). (2) Both facilitation and inactivation of presynaptic calcium currents have been observed during stimulus trains (Borst and Sakmann,

Received Sept. 27, 1999; revised Nov. 22, 1999; accepted Nov. 30, 1999.

This work was supported by National Institutes of Health Grants R01-NS32405-01 and MH/NS20017-02. We thank Adam Carter, Chinfei Chen, Jeremy Dittman, Matthew Xu-Friedman, and Kaspar Vogt for comments on this manuscript.

Correspondence should be addressed to Dr. Wade G. Regehr, Department of Neurobiology, Harvard Medical School, 220 Longwood Avenue, Boston MA 02115. E-mail: wade_regehr@hms.harvard.edu.

Copyright (C) 2000 Society for Neuroscience $\quad 0270-6474 / 00 / 201348-10 \$ 15.00 / 0$
1998; Cuttle et al., 1998; Forsythe et al., 1998; Patil et al., 1998). (3) Tonic G-protein inhibition of calcium channels may be relieved during repetitive stimulation (Bean, 1989; Elmslie et al., 1990; Herlitze et al., 1996; Ikeda, 1996; Brody et al., 1997), also leading to increased calcium influx during a train. (4) Neuromodulators can accumulate and act presynaptically to inhibit release, often through an inhibition of calcium channels (Isaacson et al., 1993; Yawo and Chuhma, 1993; Dittman and Regehr, 1997; Scanziani et al., 1997). (5) A transient decrease in the probability of release or a decrease in the number of readily releasable vesicles could depress synaptic strength during a train (Takeuchi, 1958; Elmqvist and Quastel, 1965; Betz, 1970; Silver et al., 1998). (6) High rates of presynaptic activity also increase presynaptic $\mathrm{Ca}_{\text {res}}$, which can facilitate transmission (Katz and Miledi, 1968; Kamiya and Zucker, 1994; Atluri and Regehr, 1996) and accelerate recovery from depression (Dittman and Regehr, 1998; Stevens and Wesseling, 1998; Wang and Kaczmarek, 1998).

The presence of neuromodulators can significantly alter the responses of synapses during trains (Varela et al., 1997; Brenowitz et al., 1998; Pananceau et al., 1998; Selig et al., 1999). Most mechanistic studies of modulators have characterized their effects during low-frequency stimulation. In these conditions, modulators change the probability of release either by modulating presynaptic calcium channels or by changing release probability downstream from calcium influx. However, the actions of neuromodulators in vivo occur against a background of continuous neural activity, and their effects in these conditions may be more complex (Qian and Delaney, 1997; Vyshedskiy et al., 1998). Modulators could alter the rate of calcium extrusion from the presynaptic terminal after an action potential, thereby changing the residual calcium signal for facilitation and recovery from depres- 
sion. Additionally, processes involved in short-term plasticity could be targeted directly.

Here, we test the effects of agonists of adenosine $A_{1}$ and $\mathrm{GABA}_{\mathrm{B}}$ receptors on synaptic transmission during repetitive stimulation at the parallel fiber to Purkinje cell synapse. It was found previously that for low-frequency stimulation, synaptic inhibition by these receptors is primarily a consequence of presynaptic calcium channel inhibition, although 10-30\% of the EPSC inhibition by $\mathrm{GABA}_{\mathrm{B}}$ receptors was presynaptic downstream of calcium influx (Dittman and Regehr, 1996). During trains of stimuli, the actions of these neuromodulators appear no different from those of low external calcium, and contributions from additional mechanisms, such as relief of G-protein inhibition of calcium channels, are not apparent.

\section{MATERIALS AND METHODS}

Slice preparation and solutions. Transverse slices (300 $\mu \mathrm{m}$ thick) were cut from the cerebellar vermis of 11- to 14-d-old Sprague Dawley rats. Slices were superfused with an external saline solution containing (in $\mathrm{mM}$ ): 125 $\mathrm{NaCl}, 2.5 \mathrm{KCl}, 1.5 \mathrm{CaCl}_{2}, 1 \mathrm{MgCl}_{2}, 26 \mathrm{NaHCO}_{3}, 1.25 \mathrm{NaH}_{2} \mathrm{PO}_{4}$, and 25 glucose, bubbled with $95 \% \mathrm{O}_{2} / 5 \% \mathrm{CO}_{2}$. Divalent ion concentrations were matched near reported values for rat CSF (Manthei et al., 1973), and experiments were conducted at $34 \pm 1^{\circ} \mathrm{C}$ to better simulate physiological conditions. Bicuculline $(20 \mu \mathrm{M})$ was added to the external solution to suppress synaptic currents mediated by $\mathrm{GABA}_{\mathrm{A}}$ receptors. To minimize changes in fiber excitability when switching between external solutions, divalent ion concentrations were optimized as follows: $1 \mathrm{Ca}_{\mathrm{e}}$ contained $1 \mathrm{mM} \mathrm{CaCl}_{2}$ and $1.75 \mathrm{mM} \mathrm{MgCl}_{2} ; 2 \mathrm{Ca}_{\mathrm{e}}$ saline contained $2 \mathrm{mM}$ $\mathrm{CaCl}_{2}$ and $0.25 \mathrm{mM} \mathrm{MgCl}$.

To preclude endogenous G-protein-mediated modulation during trains of stimuli, the $\mathrm{GABA}_{\mathrm{B}}$ receptor antagonist CGP55845a (2 $\left.\mu \mathrm{M}\right)$ (Davies et al., 1993), the adenosine $A_{1}$ receptor antagonist 8-cyclopentyl-1,3dipropylxanthine (DPCPX) (5 $\mu \mathrm{M})$ (Haleen et al., 1987), and the mGluRIII antagonist ( $R S)$ - $\alpha$-cyclopropyl-4-phosphonophenylglycine (CPPG) $(30 \mu \mathrm{M})$ (Jane et al., 1996) were included in the external saline. These antagonists had no effect on EPSC amplitudes during low-frequency stimulation $(<0.1 \mathrm{~Hz})(n=3$; data not shown). During modulation experiments in which the adenosine $\mathrm{A}_{1}$ agonist $N^{6}$-cyclopentyladenosine (CPA) $(2 \mu \mathrm{M})$ was added to the external saline, the concentration of DPCPX was reduced to $50 \mathrm{~nm}$. In experiments with the $\mathrm{GABA}_{\mathrm{B}}$ receptor agonist baclofen $(8 \mu \mathrm{M})$, the concentration of CGP55845a was reduced to $100 \mathrm{nM}$. By retaining a small amount of antagonist in the saline, a higher concentration of agonist could be used in these experiments. The higher concentration of agonist effectively buffered against small amounts of endogenous ligand that could accumulate and differentially depress later stimuli in a train.

Electrophysiology. Whole-cell recordings of Purkinje cells were obtained as described previously (Llano et al., 1991; Regehr and Mintz, 1994). Glass electrodes (1-1.4 M $\Omega$ ) were filled with an internal solution containing (in mM): $35 \mathrm{CsF}, 100 \mathrm{CsCl}, 10 \mathrm{EGTA}, 10 \mathrm{HEPES}$, and 0.2 D600, adjusted to $\mathrm{pH} 7.3$ with $\mathrm{CsOH}$. Synaptic currents were monitored with a holding potential of $-40 \mathrm{mV}$ to inactivate voltage-gated sodium channels, and D600 was added to block L-type voltage-gated calcium channels. Synaptic currents did not decay completely between pulses at stimulation frequencies higher than $50 \mathrm{~Hz}$, and a significant shift of the baseline current developed. This introduced series resistance errors, and it might also have signaled the prolonged presence of glutamate in the synaptic cleft, which could lead to postsynaptic receptor desensitization (Trussell and Fischbach, 1989; Trussell et al., 1993). Therefore, we did not stimulate at frequencies higher than $50 \mathrm{~Hz}$. Between trains of stimuli, single EPSCs were monitored throughout experiments to ensure that no long-term changes in synaptic strength were occurring. Because of the trial-to-trial variability in EPSC size at this synapse, the initial EPSC amplitude $\left(\mathrm{EPSC}_{1}\right)$ in a train of stimuli was calculated by averaging together the initial EPSC of a train with the three preceding single EPSCs. The access resistance, leak current $(-20$ to $-200 \mathrm{pA}$, holding at $-40 \mathrm{mV})$, and EPSC decay time constant $\left(2-4 \mathrm{msec}\right.$ at $\left.34^{\circ} \mathrm{C}\right)$ were monitored continuously. Experiments were rejected if these parameters increased significantly during recording. Parallel fibers were stimulated with two glass electrodes (tip diameter, $10-12 \mu \mathrm{m}$ ) filled with external saline solution placed in the molecular layer $\sim 15 \mu \mathrm{m}$ apart. Brief pulses $(200 \mu \mathrm{sec})$ of current $(5-15 \mu \mathrm{A})$ were passed between the two stimulating electrodes. This configuration greatly reduced the size of the stimulus artifact and allowed for a clear resolution of the EPSC onset. The interstimulus interval was $10 \mathrm{sec}$ for single stimuli, $2 \mathrm{~min}$ for trains of $\leq 10$ stimuli, and 4 min for trains of $>10$ stimuli. Low stimulus intensities were used to keep synaptic currents small $(-100$ to $-200 \mathrm{pA})$ and the resulting series resistance errors to a minimum.

Detecting presynaptic volleys. Presynaptic volleys were measured as described previously (Sabatini and Regehr, 1997). In brief, a glass electrode (tip diameter, 2-3 $\mu \mathrm{m}$; resistance, $1 \mathrm{M} \Omega$ when filled with $3 \mathrm{M} \mathrm{NaCl}$ ) was placed $200-400 \mu \mathrm{m}$ away from the stimulation site in the molecular layer near the Purkinje cell layer. Voltage records were amplified with a gain of 100 using an operational amplifier $(356 \mathrm{~N})$ mounted onto the micromanipulator. When the two stimulus electrodes were placed near the Purkinje cell layer, no significant change in either the waveform or the amplitude of the presynaptic volleys was detected during a train in $75 \%$ of fiber tracts. In $25 \%$ of tracts, the volley amplitude increased during a train, and the waveform became narrower. This effect became more pronounced and occurred more frequently when the stimulus electrodes were placed in the middle of the molecular layer. Whole-cell recordings were only established when presynaptic volley amplitudes differed by $<10 \%$ for the 1st and 10th stimulus of a $50 \mathrm{~Hz}$ train. Presynaptic fiber volleys were monitored simultaneously throughout experiments to ensure that no changes in fiber excitability occurred.

Detecting presynaptic calcium transients. Parallel fibers, made up of granule cell axons and presynaptic terminals, were labeled with a highpressure stream of the low-affinity calcium indicator magnesium green-AM (Zhao et al., 1996) (Molecular Probes, Eugene, OR) using techniques developed previously (Regehr and Tank, 1991; Regehr and Atluri, 1995; Atluri and Regehr, 1996). The loading time for magnesium green-AM was 8-10 min, and recordings commenced $2 \mathrm{hr}$ after dye loading. Parallel fiber tracts were stimulated extracellularly, and epifluorescence was measured with a photodiode from a spot several hundred micrometers from the loading site, where the vast majority of the fluorescence signal arises from parallel fiber presynaptic boutons that synapse onto Purkinje cells. The peak $\Delta F / F$ change produced by a single stimulus was used as a linear measure of presynaptic calcium influx, as established previously. The filter set for magnesium green was 470DF20 (Zeiss) for excitation, 510DRLP dichroic, and OG530 for emission (Omega Optical, Brattleboro, VT).

Data acquisition and analysis. Field recordings were filtered at $5 \mathrm{kHz}$ with a model 900C9L8L eight-pole Bessel filter (Frequency Devices, Haverhill, MA). EPSCs were filtered at $1 \mathrm{kHz}$ with a four-pole Bessel filter. Fluorescence transients were filtered digitally off-line with an eight-pole filter. All signals were digitized at $20 \mathrm{kHz}$ with a 16 bit D/A converter (Instrutech, Great Neck, NY), with Pulse Control software (Herrington and Bookman, 1995). Analysis was performed using Igor Pro software (Wavemetrics, Lake Oswego, OR).

\section{RESULTS}

The parallel fiber to Purkinje cell synapse has a number of advantages for this study. First, there is no recurrent excitation in this circuit that could contribute to later responses during a train of stimuli (Palay and Chan-Palay, 1974; Ito, 1984). Second, previous work has already examined the mechanisms by which agonists of the adenosine $\mathrm{A}_{1}$ and $\mathrm{GABA}_{\mathrm{B}}$ receptor modulate initial release probability (Dittman and Regehr, 1996). Activation of these receptors has been shown to inhibit presynaptic N-type and $\mathrm{P} / \mathrm{Q}$-type calcium channels. Third, it is possible to measure fiber excitability, presynaptic calcium transients, and postsynaptic currents at this synapse (Konnerth et al., 1990; Regehr and Atluri, 1995; Sabatini and Regehr, 1997).

Experimental conditions were chosen to approximate physiological conditions. Stimulation consisted of regular and irregular trains. Experiments were conducted at $34^{\circ} \mathrm{C}$ and divalent ion concentrations in the external saline $\left(1 \mathrm{mM} \mathrm{Mg}^{2+}, 1.5 \mathrm{mM} \mathrm{Ca}^{2+}\right.$ in control conditions) were near reported values for rat CSF (Manthei et al., 1973).

\section{Use-dependent plasticity during trains}

In control conditions, parallel fibers were stimulated with an irregular spike train whose interspike intervals followed a Poisson 

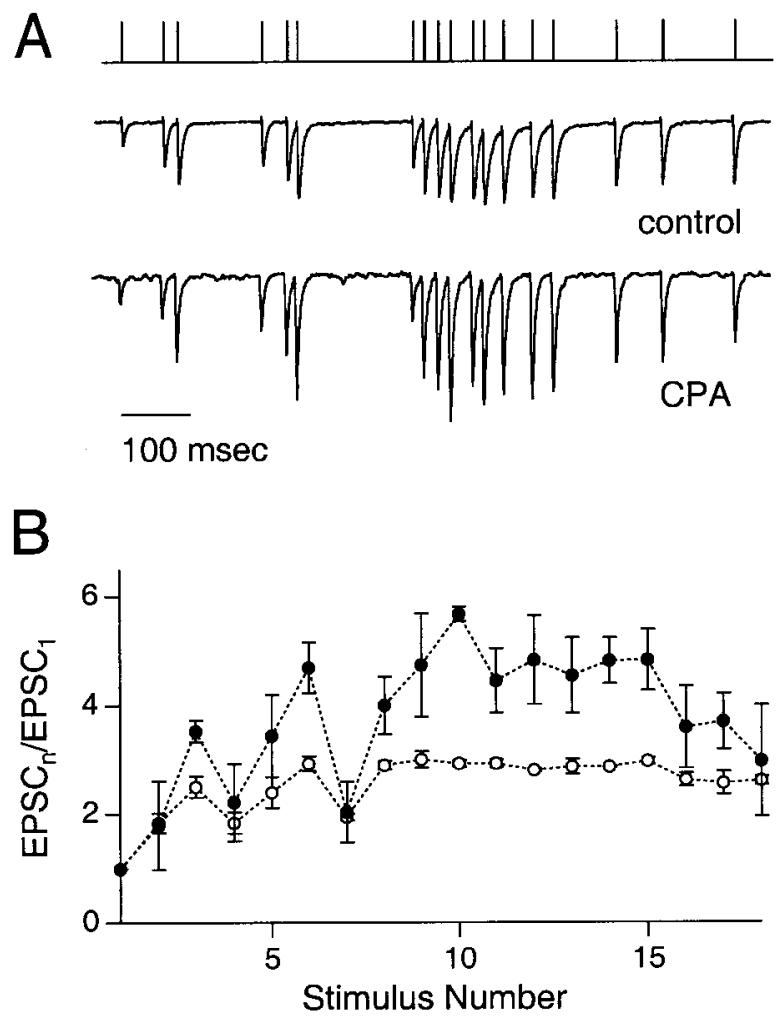

Figure 1. Parallel fiber responses to irregular stimulus trains. A, Evoked currents recorded in response to an irregular stimulus train (stimulus pattern shown at top; mean frequency, $20 \mathrm{~Hz}$ ) in control conditions and during bath application of $2 \mu \mathrm{M} \mathrm{CPA}$. Amplitudes were normalized to the initial EPSC in each trace. Traces represent averages of three trials. Before normalization, initial EPSC amplitudes were 100-200 pA in all experiments. $B$, Relative enhancement of evoked currents in control conditions $(\bigcirc)$ and during application of CPA $(\bullet)$. Plots are derived from data shown in $A$. Error bars are SD.

distribution. The amplitudes of the evoked EPSCs in Purkinje cells varied nearly threefold during stimulation (Fig. 1A). Although there were small trial-to-trial differences in EPSC amplitudes, most of the variation was stereotyped over multiple trials using this same stimulus pattern (Fig. $1 B$ ). Application of the adenosine $A_{1}$ receptor agonist CPA $(2 \mu \mathrm{M})$, along with the $A_{1}$ receptor antagonist DPCPX (50 nM) (see Materials and Methods), reduced the EPSC amplitude to $49 \pm 4 \%$ of control. In these conditions, an irregular stimulus train evoked responses that varied nearly sixfold, and this variability was reproducible over multiple trials. Therefore, in addition to changing initial release probability, presynaptic modulators of neurotransmitter release can alter synaptic responses to a pattern of presynaptic spikes.

To investigate the factors controlling synaptic strength during repetitive stimulation, both in control conditions and in the presence of neuromodulators, parallel fibers were stimulated with regular trains over a range of frequencies. We limited the trains to 10-20 pulses to minimize the contribution of post-tetanic potentiation (Magleby, 1987), long-term potentiation (Salin et al., 1996), and a slow form of synaptic depression (Dittman and Regehr, 1998; Galarreta and Hestrin, 1998). The parallel fiber responses exhibited sustained facilitation of neurotransmitter release in response to trains of 10 stimuli (Fig. 2A). This facilitation built up over the first five to six pulses and reached a steady state that was maintained for 150-200 pulses (data not shown). The
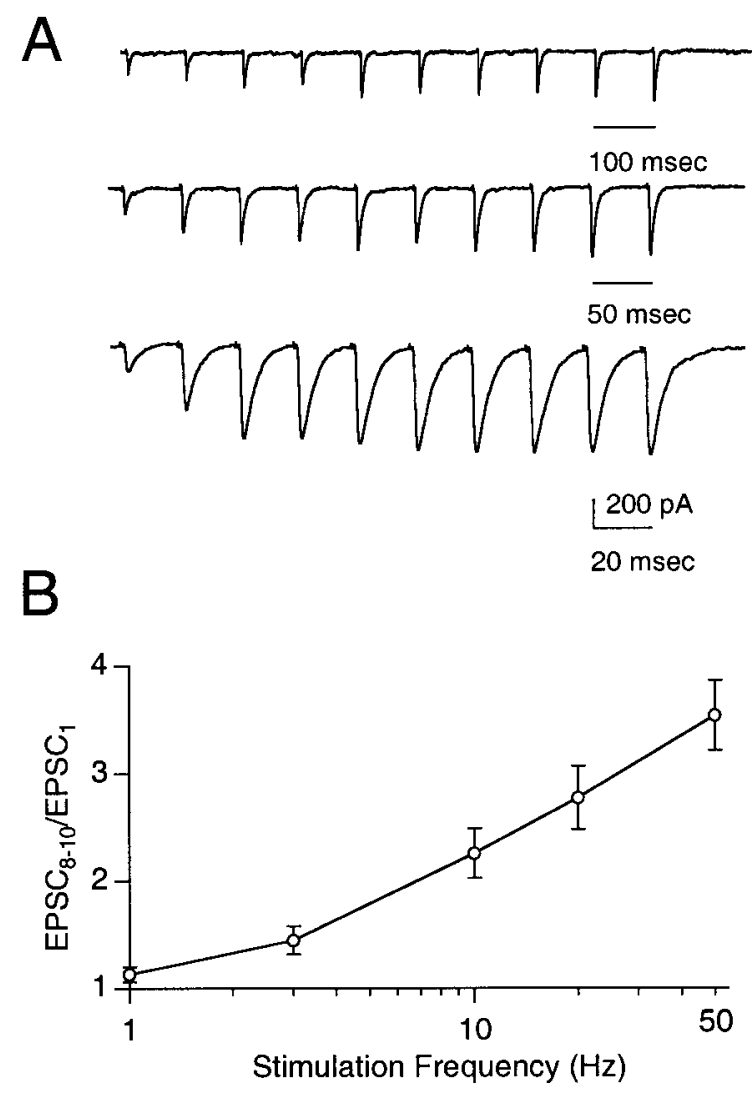

Figure 2. Frequency responses of parallel fiber synaptic currents. $A$, Representative traces in response to regular trains of 10 pulses at 10, 20, and $50 \mathrm{~Hz}$. Traces represent averages of three to four trials. $B$, Mean relative enhancement of evoked currents at $1,3,10,20$, and $50 \mathrm{~Hz}(n=$ 5 cells). EPSC $_{8-10}$ represents the average of the peak EPSC amplitudes of pulses 8, 9, and 10. Error bars are SEM.

magnitude of this facilitation varied with stimulation frequency, with a maximal enhancement at $50 \mathrm{~Hz}$ of $350 \pm 30 \%$ of control (Fig. 2B).

A number of use-dependent processes could contribute to the variation observed in evoked responses during sustained stimulation. (1) High stimulation rates have been demonstrated to increase the excitability of presynaptic fibers (Kocsis et al., 1983). (2) The width of the presynaptic action potential waveform could change. (3) The calcium influx in response to an action potential could facilitate or decrease during a train. (4) Endogenous ligands such as adenosine, GABA, and glutamate may accumulate and depress the release of neurotransmitter. (5) Increases in $\mathrm{Ca}_{\text {res }}$, which typically last several hundred milliseconds after elevated presynaptic activity, could increase the magnitude of facilitation and speed recovery from depression. To understand the changes in synaptic strength we observe during a train, we next evaluated the contributions from each of these mechanisms.

We used an extracellular electrode to monitor the presynaptic volley, which is produced by the current flow associated with propagating action potentials. The magnitude of the presynaptic volley is proportional to the number of fibers stimulated, and its shape can be used to detect changes in the presynaptic waveform (Sabatini and Regehr, 1997). We simultaneously monitored field potentials during all whole-cell recording and optical imaging. Figure $3 A$ shows a representative field potential recording during a $50 \mathrm{~Hz}$ stimulus train. The changes in the amplitude and the 


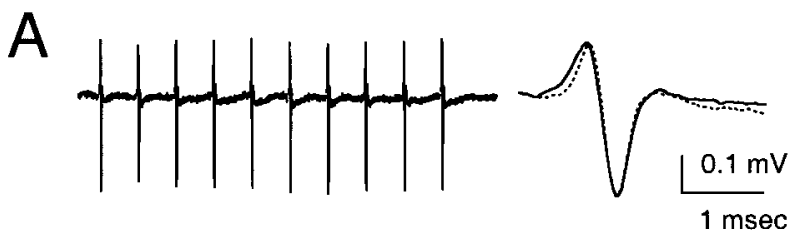

$\overline{40 \mathrm{msec}}$

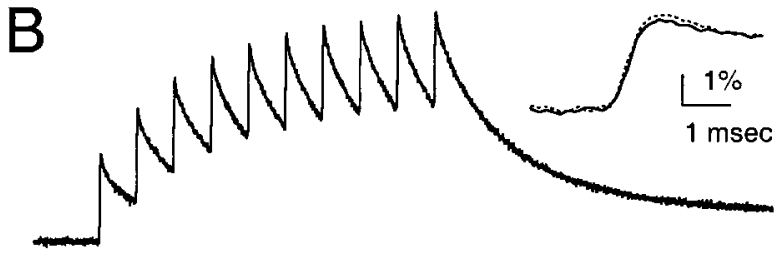

Figure 3. Presynaptic volley and calcium influx during a train of stimuli. $A$, Presynaptic volleys recorded in $1.5 \mathrm{Ca}_{\mathrm{e}}$ in response to $50 \mathrm{~Hz}$ stimulation. Stimulus artifacts have been blanked for clarity. Inset, No major changes occur in either the waveform or amplitude of the volley between pulse 1 (solid line) and pulse 10 (dotted line). Traces represent averages of 10 trials. $B$, Presynaptic calcium transients measured with the low-affinity indicator magnesium green in response to a $50 \mathrm{~Hz}$ train of stimuli. Inset, There is little change in calcium influx per pulse between pulse 1 (solid line) and pulse 10 (dotted line). On average, pulse 10 was enhanced by $14 \pm$ $5 \%(n=4)$ in control conditions. Traces are the averages of 20 trials.

waveform of the presynaptic volley between pulses 1 and 10 were small. This suggests that in control conditions, the presynaptic action potential stays approximately the same size and the same number of fibers is activated for each stimulus in the train.

Optical methods were used to detect changes in presynaptic calcium influx (Regehr and Atluri, 1995). To monitor $\mathrm{Ca}_{\text {res}}$, we loaded granule cell terminals with the low-affinity calciumsensitive fluorophore magnesium green (Atluri and Regehr, 1996; Z hao et al., 1996). Because granule cell presynaptic boutons are small ( $<1 \mu \mathrm{m}$ in diameter) (Palay and Chan-Palay, 1974), calcium gradients dissipate rapidly. Therefore several milliseconds after stimulation, the normalized changes in magnesium green fluorescence $(\Delta F / F)$ provide a good estimate of $\mathrm{Ca}_{\text {res }}$ dynamics (Atluri and Regehr, 1996, 1998; Sabatini and Regehr, 1998). In control conditions, a train of 10 stimuli at $50 \mathrm{~Hz}$ elicited only a slight increase in $\Delta F / F$ per stimulus between pulses 1 and 10 (pulse 10 was $114 \pm 5 \%$ of pulse $1, n=4$ ) (Fig. $3 B$ ). For magnesium green, which is a low-affinity indicator, there is a linear relationship between the change in $\Delta F / F$ and $\mathrm{Ca}_{\text {res. }}$. These results therefore indicate that changes in calcium influx per pulse during a train are small (see Discussion).

To test the hypothesis that an accumulation of metabotropic receptor ligands inhibit transmitter release during repetitive stimulation, we added to the external saline high-affinity antagonists to adenosine $A_{1}$ receptors (DPCPX: $5 \mu \mathrm{M}$ ), GABA $\mathrm{B}_{\mathrm{B}}$ receptors (CGP55845a: $2 \mu \mathrm{M}$ ), and type II/III mGluR receptors (CPPG: 30 $\mu \mathrm{M})$. These drugs did not affect baseline synaptic strength $(n=3$; data not shown), nor did they appear to impact the amount of facilitation observed during short trains of pulses $(n=4$; data not shown). Nevertheless, in subsequent experiments, antagonists were used to preclude any possible contributions of these receptors (5 $\mu \mathrm{M}$ DPCPX, $2 \mu \mathrm{M}$ CGP55845, $30 \mu \mathrm{M}$ CPPG).

In control conditions, we have found little contribution from mechanisms (1)-(4) (outlined above). Therefore, the variation in synaptic responses that we observe is likely attributable to shortterm plasticities such as facilitation and recovery from depression, which are driven by $\mathrm{Ca}_{\text {res }}$ (Kamiya and Zucker, 1994; Atluri and Regehr, 1996; Dittman and Regehr, 1998). It is apparent in Figure 3 that $\mathrm{Ca}_{\text {res }}$ levels are significantly elevated during a train of action potentials. Therefore, we hypothesize that the interaction between these calcium-dependent processes shapes the amount of transmitter released during sustained activity.

\section{The effects of external calcium during regular trains}

We next examined the effect of changing calcium entry by changing the calcium concentration in the external solution. This manipulation affects both the high local calcium signal driving neurotransmitter release as well as the residual calcium signal driving facilitation and recovery from depression.

Before characterizing the effects of external calcium $\left(\mathrm{Ca}_{\mathrm{e}}\right)$ during a train, it was first necessary to examine the dependence of single stimuli on $\mathrm{Ca}_{\mathrm{e}}$. Shown in Figure 4 are examples of an external solution change from 1.5 to $2 \mathrm{Ca}_{\mathrm{e}}$. In the experiments shown, changing to $2 \mathrm{Ca}_{\mathrm{e}}$ increased calcium influx to $131 \%$ of control and increased the EPSC to $177 \%$ of control (Fig. $4 A$ ). The effect of lowering $\mathrm{Ca}_{\mathrm{e}}$ to $1 \mathrm{~mm}$ was also assessed. On the basis of a number of such experiments we can approximate the relationship between calcium influx and EPSC amplitude to be a power law (Dodge and Rahamimoff, 1967), EPSC $=k\left(\mathrm{Ca}_{\text {influx }}\right)^{\mathrm{n}}$, where $k$ is a constant, $\mathrm{Ca}_{\text {influx }}$ represents the total presynaptic calcium influx during an action potential, and $n=2.9$ (Fig. $4 B$ ) at $34^{\circ} \mathrm{C}$. This compares with previous estimates at $24^{\circ} \mathrm{C}$ of $n=2.5$ (Mintz et al., 1995) and $n=3.1$ (Sabatini and Regehr, 1997).

Changes in external calcium concentration not only modified the amplitude of single EPSCs but also dramatically affected the degree of enhancement during trains (Fig. 5). Relative enhancement, defined as the average response to pulses 8-10 normalized to the synaptic response evoked by the first stimulus, was less in 2 $\mathrm{Ca}_{\mathrm{e}}$ than in $1 \mathrm{Ca}_{\mathrm{e}}$. The enhancement in $2 \mathrm{Ca}_{\mathrm{e}}$ appeared to saturate quickly during the train, but in $1 \mathrm{Ca}_{\mathrm{e}}$ continued to build up until approximately the seventh pulse (Fig. 5A). The relative enhancements observed in different values of $\mathrm{Ca}_{\mathrm{e}}$ for a range of frequencies (Fig. $5 B$ ) provide an indication of the dynamic range of this synapse in various conditions.

Another way of comparing the effect of external calcium on synaptic plasticity is to consider absolute enhancement (Fig. $5 C$ ), which we define as the average of the responses to pulses $8-10$, normalized to the synaptic response evoked by the first stimulus in control conditions. The absolute values were derived by scaling the relative enhancement in 1 and $2 \mathrm{Ca}_{\mathrm{e}}$ by 49 and $186 \%$, respectively; these scaling factors represent the changes in single EPSC amplitudes produced by changing $\mathrm{Ca}_{\mathrm{e}}$, as summarized in Figure 4. During high-frequency stimulation, steady-state EPSC amplitudes approach a similar absolute value in $1,1.5$, and $2 \mathrm{Ca}_{\mathrm{e}}$ (Fig. $5 C$ ). Because the effect of $\mathrm{Ca}_{\mathrm{e}}$ on synaptic strength was less pronounced at $50 \mathrm{~Hz}$ (Fig. $5 D$ ), this suggests that faster firing rates can relieve the effects of calcium-dependent modulation at this synapse.

\section{Synaptic modulation during regular trains}

We next examined the effects of neuromodulators on synaptic transmission during repetitive stimulation. On the basis of what is known about the calcium dependence of synaptic plasticity, and what we have shown here for low versus high $\mathrm{Ca}_{\mathrm{e}}$, such changes in calcium entry will clearly contribute to changes in the behavior of synapses during trains. Whether additional mechanisms contribute significantly to the effects of neuromodulators during repetitive stimulation is an open question. 

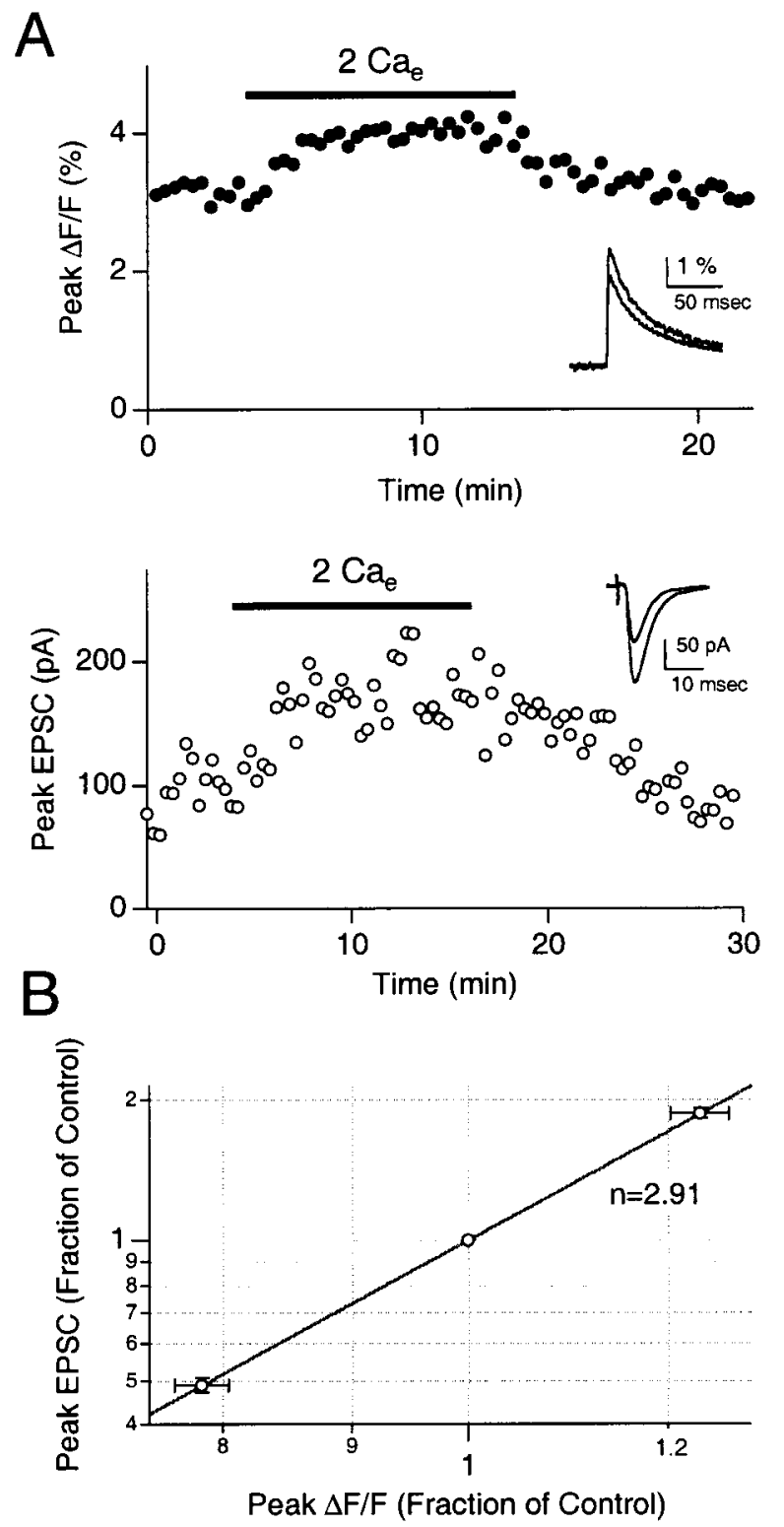

Figure 4. Relationship between presynaptic calcium influx and synaptic strength. $A$, Increase in peak fluorescence transients ( $)$ and peak EPSC amplitudes $(\bigcirc)$ during a change from 1.5 to $2 \mathrm{Ca}_{\mathrm{e}}$. Peak EPSC amplitudes each represent the average of two trials. Insets, Averaged traces in 1.5 and $2 \mathrm{Ca}_{\mathrm{e}} . B$, Peak EPSC amplitude for $1 \mathrm{Ca}_{\mathrm{e}}(n=4$ cells $)$ and $2 \mathrm{Ca}_{\mathrm{e}}(n=4$ cells) plotted as a function of peak $\Delta F / F$ per stimulus $\left(n=4,1 \mathrm{Ca}_{\mathrm{e}} ; n=\right.$ 4, $2 \mathrm{Ca}_{\mathrm{e}}$ ). Peak values are normalized to values in $1.5 \mathrm{Ca}_{\mathrm{e}}$ (mean inhibition in $1 \mathrm{Ca}_{\mathrm{e}}, 49 \pm 2 \%$ of control; mean enhancement in $2 \mathrm{Ca}_{\mathrm{e}}$, $186 \pm 5 \%$ of control). Data points are well fit to a power law function with $n=2.91$.

We tested the effects of presynaptic inhibition on synaptic transmission during trains. Periods of high-frequency activity can lead to the buildup of extracellular levels of GABA and adenosine, which are then detected by receptors on the presynaptic terminals and ultimately inhibit synaptic transmission. At the granule cell to Purkinje cell synapse, activation of adenosine $A_{1}$ and $\mathrm{GABA}_{\mathrm{B}}$ receptors has been shown to reduce the amplitude of single pulses primarily through an inhibition of presynaptic calcium channels (Dittman and Regehr, 1996). Our basic strategy was to compare the effects of $A_{1}$ and $G_{A B A}$ receptor inhibition with low $\mathrm{Ca}_{\mathrm{e}}$ on synaptic transmission during trains. We used
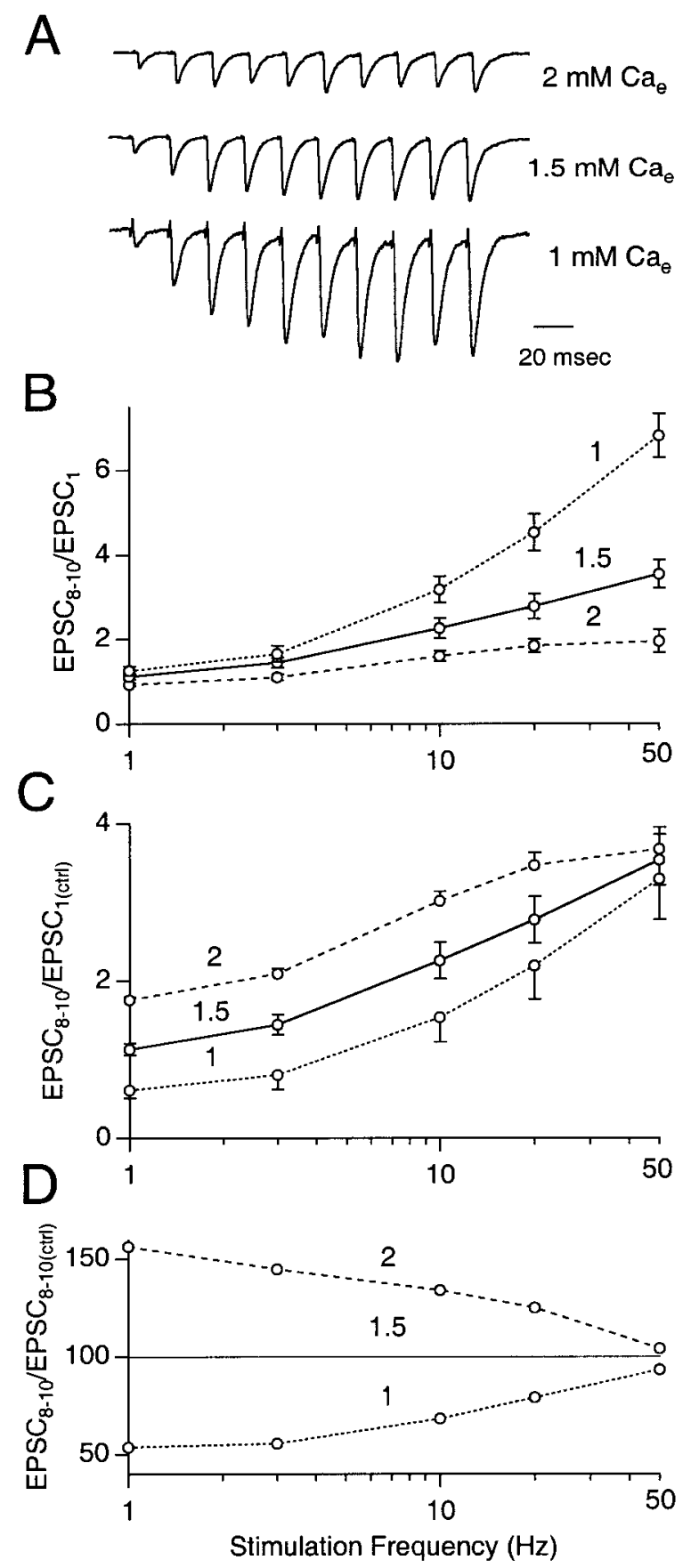

Figure 5. Frequency responses in different external calcium concentrations. $A$, Representative traces recorded in $1,1.5$, and $2 \mathrm{Ca}_{\mathrm{e}}$ in response to $50 \mathrm{~Hz}$ stimulation. Amplitudes are normalized to the initial EPSC. Traces represent averages of three to four trials. $B$, Mean relative enhancement of evoked currents in 1 (dotted line, $n=5$ cells), 1.5 (solid line, $n=5$ cells), and $2 \mathrm{Ca}_{\mathrm{e}}$ (dashed line, $n=5$ cells) at stimulation frequencies of 1, 3, 10, 20, and $50 \mathrm{~Hz}$. $C$, Mean absolute enhancement in 1, 1.5, and 2 $\mathrm{Ca}_{\mathrm{e}}$ plotted as a function of stimulation frequency. Absolute values in 1 and $2 \mathrm{Ca}_{\mathrm{e}}$ have been derived by scaling relative values according to data shown in Figure 4. D, Absolute enhancement of EPSC amplitudes during trains in 1 and $2 \mathrm{Ca}_{\mathrm{e}}$ as a percentage of control values. Error bars are SEM.

different concentrations of $\mathrm{Ca}_{\mathrm{e}}$ to determine how synaptic strength changes during trains when only calcium influx has been altered. If modulation of transmission by $\mathrm{GABA}_{\mathrm{B}}$ receptors and $\mathrm{A}_{1}$ receptors uses additional mechanisms, these modulators might affect the train differently from low $\mathrm{Ca}_{\mathrm{e}}$. 


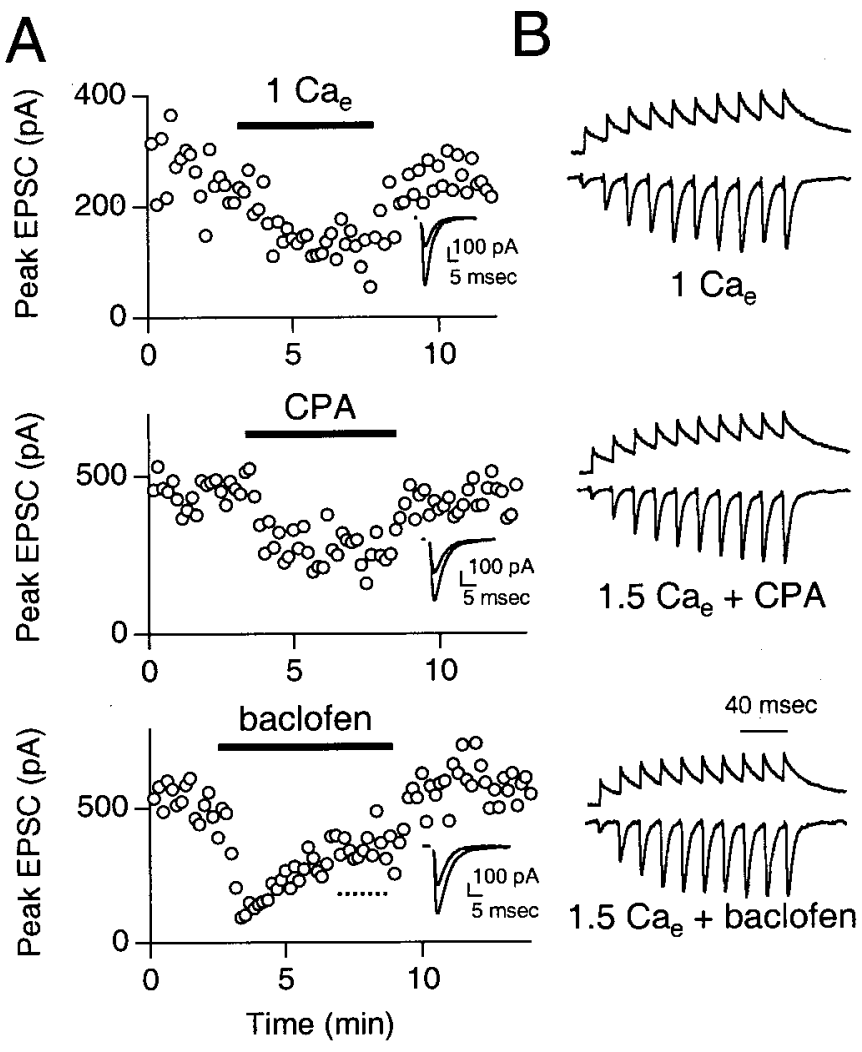

Figure 6. Modulation of synaptic strength with $1 \mathrm{Ca}_{\mathrm{e}}, \mathrm{CPA}$, and baclofen. $A$, Reduction in peak single EPSC amplitude during exposure to $1 \mathrm{Ca}_{\mathrm{e}}, \mathrm{CPA}$, and baclofen (see Materials and Methods). Control solution contained $1.5 \mathrm{Ca}_{\mathrm{e}}$. The dashed line below the data for baclofen indicates the times at which steady-state responses were measured. Insets, Averaged traces in control conditions and after modulation. $B$, Representative EPSC and $\Delta F / F$ traces during $50 \mathrm{~Hz}$ stimulation in $1 \mathrm{Ca}_{\mathrm{e}}, \mathrm{CPA}$, and baclofen. Traces represent averages of three to four trials (EPSC) and $15-20$ trials $(\Delta F / F)$.

Our first step in these experiments was to choose concentrations of neuromodulators that reduced single EPSC amplitudes by a degree similar to that of $1 \mathrm{Ca}_{\mathrm{e}}$ (Fig. 6A). Reducing $\mathrm{Ca}_{\mathrm{e}}$ to $1 \mathrm{~mm}$ decreased the EPSC to $49 \pm 2 \%$ of control $(n=4)$. A combination of a receptor agonist and antagonist was used to inhibit transmission (see Materials and Methods). For the adenosine $\mathrm{A}_{1}$ receptor, $2 \mu \mathrm{M}$ of the agonist $\mathrm{CPA}$ and $50 \mathrm{~nm}$ of the antagonist DPCPX reduced the EPSC to $49 \pm 4 \%$ of control $(n=4)$. For the $\mathrm{GABA}_{\mathrm{B}}$ receptor, $8 \mu \mathrm{M}$ of the agonist baclofen and $100 \mathrm{~nm}$ of the antagonist CGP55845a decreased the EPSC to $52 \pm 4 \%$ of control $(n=5)$.

For baclofen, inhibition was maximal immediately after drug application, and a steady-state value was reached in $\sim 3-5 \mathrm{~min}$. This effect was reliably observed, and we restricted our analysis of baclofen inhibition to times in which a clear steady state had been reached. Because we used a combination of an agonist and antagonist (see Materials and Methods), this effect may have arisen from a slow equilibration of these molecules with receptor binding sites. This effect is not prominent when baclofen is washed in alone (Dittman and Regehr, 1996).

We next assessed the effects of these manipulations on presynaptic calcium transients and EPSCs during trains. Shown in Figure $6 B$ are normalized representative traces of 10 stimuli at 50 $\mathrm{Hz}$ in each condition. During trains, no differences were observed

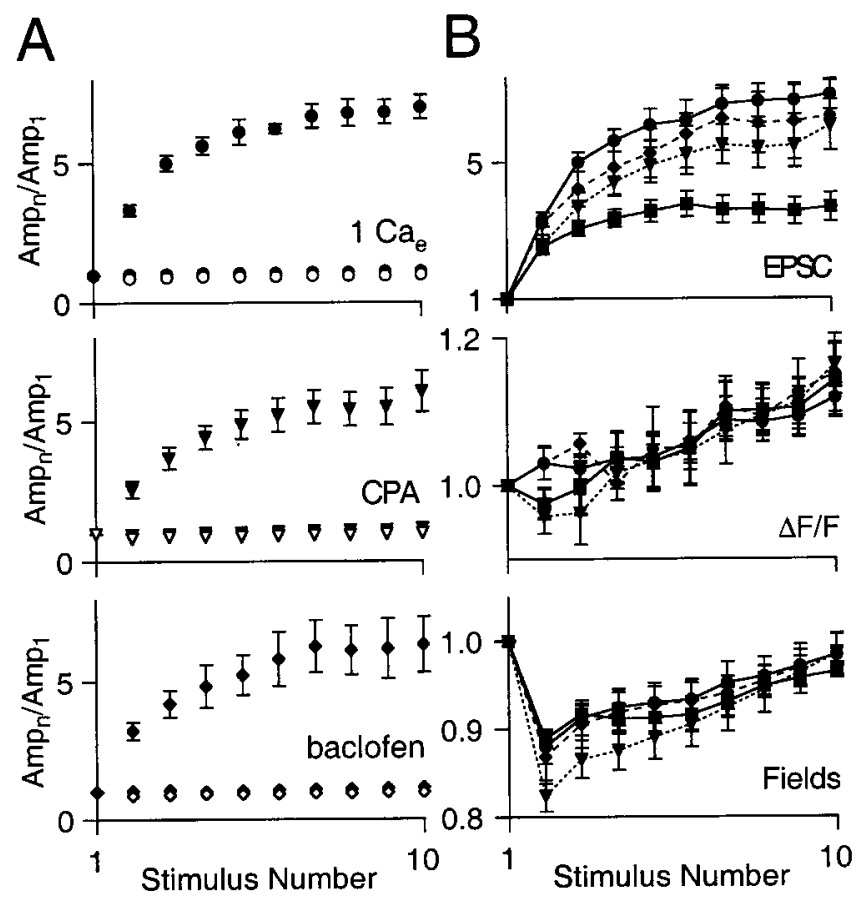

Figure 7. Mean enhancement during repetitive stimulation in $1 \mathrm{Ca}_{\mathrm{e}}$, CPA, and baclofen. $A$, Mean relative changes in EPSC (black with error bars), $\Delta F / F$ (black), and presynaptic volley (white) amplitudes during 50 $\mathrm{Hz}$ stimulation in $1 \mathrm{Ca}_{\mathrm{e}}$ (circles), CPA (triangles), and baclofen (diamonds). $B$, Mean relative changes in EPSC, $\Delta F / F$, and presynaptic volley, on an expanded scale, in $1 \mathrm{Ca}_{\mathrm{e}}$ (circles, solid line, $n=5$ cells), CPA (triangles, dotted line, $n=6$ cells), and baclofen (diamonds, dashed line, $n=5$ cells). Control $\left(1.5 \mathrm{Ca}_{\mathrm{e}}\right)$ traces (squares, solid line, $n=5$ cells) are shown for comparison. Error bars are SEM.

in the presynaptic calcium transients or EPSC amplitudes between low $\mathrm{Ca}_{\mathrm{e}}, \mathrm{CPA}$, and baclofen.

Because relative synaptic enhancement was maximal during high-frequency stimulation, we examined the effect of $50 \mathrm{~Hz}$ stimulation on the EPSC, $\Delta F / F$, and presynaptic volley more closely for low $\mathrm{Ca}_{\mathrm{e}}$, baclofen, and CPA in Figure 7. During these manipulations, the EPSC amplitude during the train was greatly enhanced, whereas by comparison, the calcium influx and the fiber excitability exhibited only small changes, which were no different from control conditions. A comparison of the effects of the modulators and $1 \mathrm{Ca}_{\mathrm{e}}$ reveals that all manipulations produced a five- to sixfold enhancement of EPSC amplitude (Fig. 7A), which is significantly more than the threefold enhancement in control conditions. Plotting the $\Delta F / F$ signals and the presynaptic volley amplitude (Fig. $7 B$ ) on a greatly expanded scale reveals the changes in $\Delta F / F$ per pulse and in the presynaptic volley amplitude during the train. The extent of the increase in $\Delta F / F$ per pulse is similar in control conditions, $1 \mathrm{Ca}_{\mathrm{e}}$, and in the presence of the neuromodulators. Compared with the 1st pulse, the 10th pulse evokes $10-15 \%$ more calcium influx. For all conditions tested, the presynaptic volley evoked by the second stimulus in the train declined by $12-18 \%$. The amplitude of subsequent volleys then gradually increased during the train, so that by the 10th pulse the presynaptic volley amplitude was comparable to that evoked by the first pulse. These small changes in fiber excitability and calcium influx could not account for the very large synaptic enhancement observed during the train (see Discussion).

At all frequencies tested, the effects of low $\mathrm{Ca}_{e}, \mathrm{CPA}$, and baclofen on synaptic plasticity were similar to each other and 

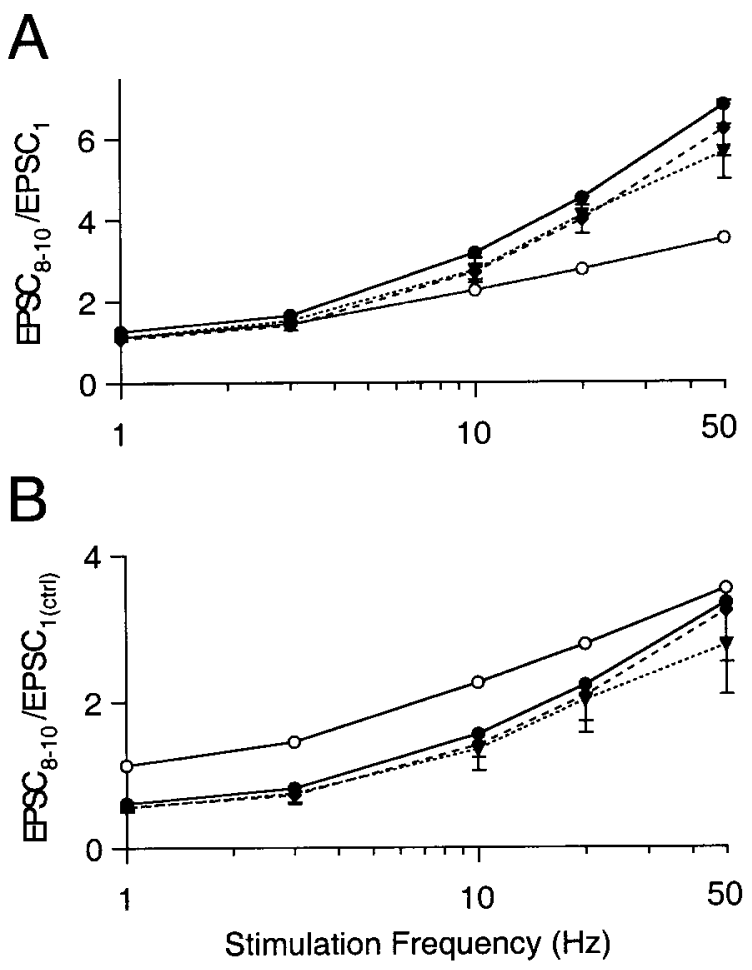

Figure 8. Frequency responses in CPA and baclofen. $A$, Mean relative enhancement at $1,3,10,20$, and $50 \mathrm{~Hz}$ after application of CPA (triangles, dotted line, $n=6$ cells) and baclofen (diamonds, dashed line, $n=5$ cells). Shown for comparison are $1 \mathrm{Ca}_{\mathrm{e}}$ ( filled circles, solid line, $n=5$ cells) and $1.5 \mathrm{Ca}_{\mathrm{e}}$ (open circles, solid line, $n=5$ cells). $B$, Absolute enhancement derived by scaling relative values by data shown in Figure 6. Error bars are SEM.

significantly different from control conditions. This is apparent in plots of both the relative steady-state enhancement (Fig. 8A) and the absolute steady-state enhancement (Fig. $8 B$ ) as a function of stimulus frequency. This result suggests that despite the differences in the power law dependencies of these modulators on presynaptic calcium influx, changes in initial release probability were most important in shaping synaptic responses during trains.

\section{Synaptic modulation during irregular trains}

We also examined the behavior of synapses during irregular stimulus trains for various experimental conditions (Fig. 9A). Compared with control conditions, there was more enhancement and greater variability in the presence of adenosine $A_{1}$ and $\mathrm{GABA}_{\mathrm{B}}$ receptor agonists and in low $\mathrm{Ca}_{\mathrm{e}}$. Bursts of stimuli resulted in a greater relative enhancement of transmitter release in the presence of neuromodulators. This is apparent in examining the responses to pulses 2-3, pulses 4-6, and pulses 7-10. Therefore, even during more realistic spike trains, the effects of these neuromodulators are no different than the effect of low $\mathrm{Ca}_{\mathrm{e}}$ (Fig. 9B).

\section{DISCUSSION}

We found that during repetitive stimulation, parallel fiber synapses show significant enhancement that becomes more profound when transmission is inhibited by activating presynaptic metabotropic receptors. In all conditions, changes in fiber excitability and calcium influx during the train cannot account for the bulk of this enhancement, which is likely a consequence of facilitation of the release apparatus. Measurements of the EPSC amplitude, presyn-
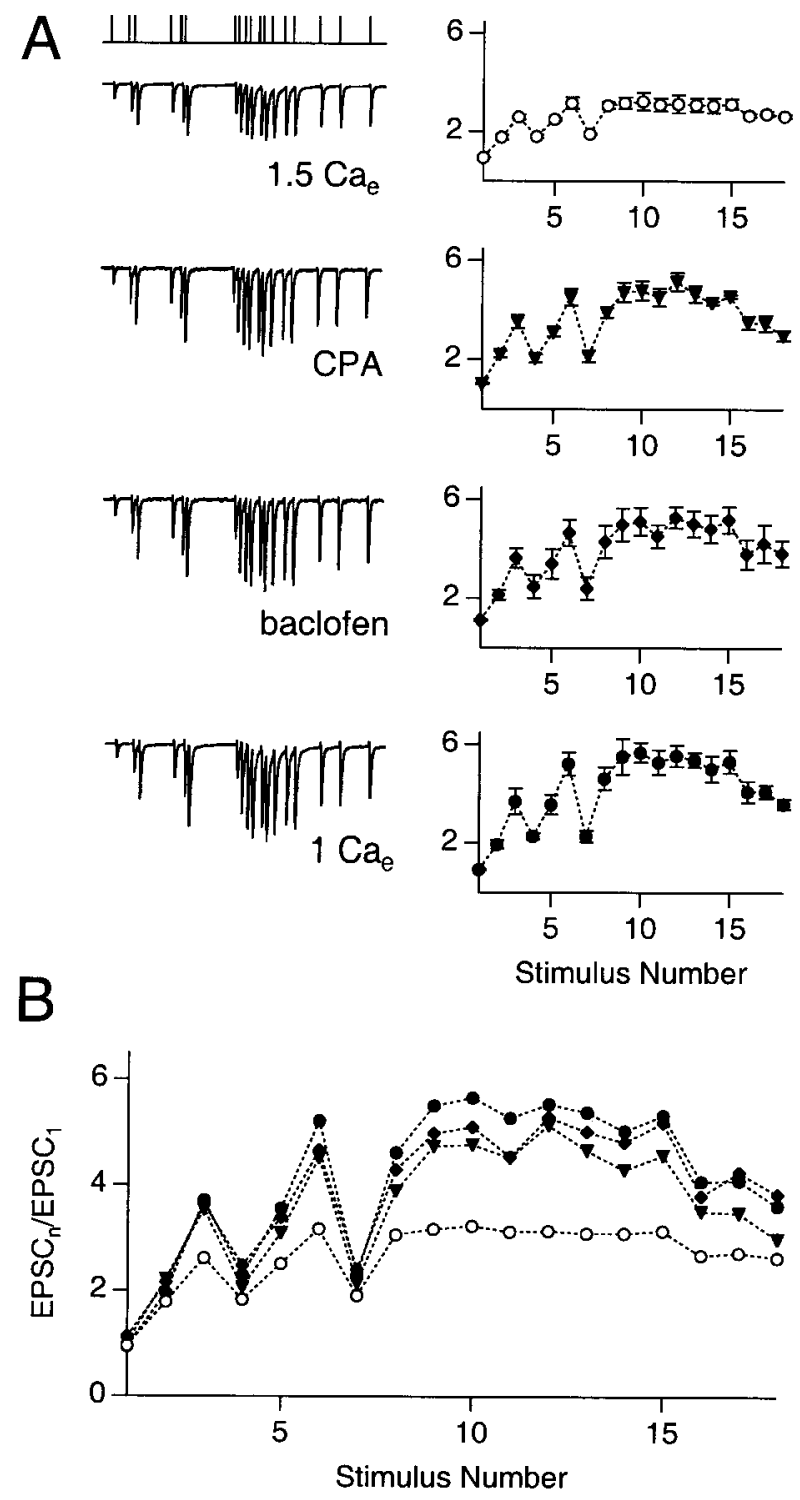

Figure 9. Responses to irregular stimuli in $1.5 \mathrm{Ca}_{\mathrm{e}}, \mathrm{CPA}$, baclofen, and $1 \mathrm{Ca}_{\mathrm{e}} . A$, Left, Average evoked currents in response to a $20 \mathrm{~Hz}$ irregular stimulus train (stimulus pattern shown above). Right, Mean enhancement in $1.5 \mathrm{Ca}_{\mathrm{e}}$ (open circles, $n=3$ cells), $1 \mathrm{Ca}_{\mathrm{e}}$ ( filled circles, $n=4$ cells), baclofen (diamonds, $n=3$ cells), and CPA (triangles, $n=3$ cells). Error bars are SEM. $B$, Mean enhancement in $1.5 \mathrm{Ca}_{\mathrm{e}}, \mathrm{CPA}$, baclofen, and 1 $\mathrm{Ca}_{\mathrm{e}}$ (same symbols as in $A$ ).

aptic volley, and calcium influx during trains in various experimental conditions constrain the mechanism responsible for synaptic enhancement.

\section{Do changes in fiber excitability or calcium influx contribute to synaptic plasticity during trains?}

For all conditions tested, presynaptic volley amplitudes declined by $12-18 \%$ for the second stimulus, and then gradually returned to original values by the 10 th stimulus. Changes in the number of fibers stimulated and alterations in the current flow in individual fibers can both contribute to changes in the presynaptic volley amplitude. Previous results with voltage-sensitive dyes at this synapse suggest that the peak of the action potential changes very little during short high-frequency trains, whereas the baseline voltage is substantially elevated because of a long-lasting after- 
depolarization of fibers after the first pulse in a train (Sabatini and Regehr, 1997). The decrease in the presynaptic volley amplitude that we observe on the second pulse is consistent with a smaller baseline-to-peak action potential in these fibers. The gradual increase in volley amplitude between pulses 2 and 10 is likely attributable to an increase in the number of fibers stimulated. Because there is a linear relationship between the number of fibers excited and synaptic strength, we can conclude that changes in fiber excitability are small relative to the EPSC enhancement that we observe and therefore do not contribute significantly to synaptic plasticity during trains.

Measurements of $\Delta F / F$ for the calcium-indicator magnesium green provide an upper limit for the changes in calcium influx per pulse during repetitive activation. The change in $\Delta F / F$ per stimulus gradually increased during the train, and by the 10th pulse was $\sim 15 \%$ larger in all conditions. If the change in $\Delta F / F$ per spike reflects an increase in calcium entry, it is possible to estimate its contribution to the enhancement during the train. Considering the observed power law relating influx and release with $n=2.9$, a $15 \%$ increase in calcium influx would result in an EPSC enhancement of $50 \%$. This is an upper bound, because calcium cooperativity declines during facilitation (Stanley, 1986). If, on the other hand, the increase in $\Delta F / F$ represents an increased number of excited fibers, as suggested by the presynaptic volley measurements, then a $15 \%$ increase in the number of stimulated fibers would result in a maximal EPSC enhancement of only $15 \%$ by the 10th pulse. By comparison, the EPSC enhancement ranges from $250 \%$ for control conditions to $>500 \%$ for other conditions.

The increase in $\Delta F / F$ per spike could arise in several ways. It may represent a small facilitation of the calcium current associated with faster channel opening during a train of action potentials (Borst and Sakmann, 1998; Cuttle et al., 1998). Saturation of the endogenous calcium buffer could also contribute. It may also arise from changes in the number of activated fibers. Relief of G-protein-mediated calcium channel inhibition by a train of action potentials (Brody et al., 1997) does not likely contribute significantly, because the increase in $\Delta F / F$ per spike was the same in control conditions, and in the presence of either antagonists or agonists of presynaptic $A_{1}$ or $\mathrm{GABA}_{\mathrm{B}}$ receptors. Whatever the mechanism responsible for the increase in $\Delta F / F$ per spike, these findings establish that changes in calcium influx are small and could not account for most of the synaptic enhancement.

\section{Enhancement during regular trains}

Previous studies of paired-pulse facilitation at this synapse showed that the enhancement of the EPSC evoked by the second of two closely spaced stimuli is caused by enhanced transmitter release driven by $\mathrm{Ca}_{\text {res }}$ (Atluri and Regehr, 1996). It is likely that most of the enhancement during trains is a result of this calciumdriven process. Although there are many potential modulatory targets that would impact transmission during trains, we found that the effects of activating presynaptic $A_{1}$ receptors and $\mathrm{GABA}_{\mathrm{B}}$ receptors during trains can be explained in terms of calcium channel inhibition. The effects of baclofen, CPA, and low $\mathrm{Ca}_{\mathrm{e}}$ on synaptic strength during trains are indistinguishable. The inhibition of calcium channels is therefore the most important site of action for these modulators. Changing calcium influx has complex actions because it alters the initial release probability and $\mathrm{Ca}_{\text {res }}$, thereby affecting calcium-driven processes such as facilitation and recovery from depression.

These findings do not preclude the contribution of additional mechanisms, but they indicate that such mechanisms are not the primary determinants of the behavior of these synapses during high-frequency trains. For example, we know that there are subtle differences in inhibition at this synapse by $A_{1}$ receptors and $\mathrm{GABA}_{\mathrm{B}}$ receptors. Activation of $\mathrm{A}_{1}$ receptors inhibits $\mathrm{N}$-type calcium channels to a greater extent than $\mathrm{P} / \mathrm{Q}$-type channels. Activation of $\mathrm{GABA}_{\mathrm{B}}$ receptors inhibits $\mathrm{P} / \mathrm{Q}$-type calcium channels to a greater extent than $\mathrm{N}$-type channels, and a small fraction of the inhibition also appears to be mediated by effects downstream from calcium influx (Dittman and Regehr, 1996). Despite such mechanistic differences, the dominant behavior during trains, when either of these metabotropic receptors is activated, is well approximated by lowering $\mathrm{Ca}_{\mathrm{e}}$.

\section{Effects of modulation on synaptic filtering properties}

Manipulations that alter calcium entry affect plasticity during trains in interesting ways. Activation of $\mathrm{A}_{1}$ or $\mathrm{GABA}_{\mathrm{B}}$ receptors, or lowering $\mathrm{Ca}_{\mathrm{e}}$, decreased synaptic strength by nearly one-half at low firing rates, whereas it nearly doubled steady-state enhancement at high firing rates. In contrast, high $\mathrm{Ca}_{\mathrm{e}}$ nearly doubled synaptic strength at low frequencies, but at faster firing rates reduced enhancement by one-half. At this synapse, altering presynaptic calcium influx preferentially affects low-frequency activity (Fig. 5). Presynaptic inhibition via $A_{1}$ or $\mathrm{GABA}_{\mathrm{B}}$ receptors, or low $\mathrm{Ca}_{\mathrm{e}}$, also accentuated synaptic variability during irregular trains (Fig. 9).

These alterations in the frequency dependence of enhancement, and in synaptic variability, indicate that changing calcium influx affects the synaptic filtering properties of synapses. Presynaptic inhibition by neuromodulators reduces release probability while simultaneously increasing the amount of relative facilitation. By reducing the sensitivity of the synapse to isolated stimuli, presynaptic inhibition effectively increases the signal-to-noise ratio of synapses, were information to be encoded in bursts (Lisman, 1997).

\section{Comparisons to other synapses}

Virtually all synapses display use-dependent plasticity and synaptic variability for patterns of activity similar to those used here. At most synapses, it has been difficult to determine the mechanisms responsible for such changes in synaptic strength, because it is hard to assess spike invasion of presynaptic terminals and to measure presynaptic calcium transients. For these reasons, most mechanistic studies during repetitive stimulation have focused primarily on synapses such as the squid giant synapse or the calyx of Held, where it is possible to record electrically from the presynaptic terminal. At the squid giant synapse, changes in the presynaptic action potential waveform or calcium influx do not contribute to facilitation (Charlton and Bittner, 1978; Charlton et al., 1982). At the calyx of Held, repetitive activity depresses transmission in most experimental conditions yet enhances calcium influx per spike (Borst and Sakmann, 1998; Cuttle et al., 1998). The enhancement of calcium influx is a result of accelerated calcium channel activation kinetics and can be as much as twofold during a short train.

Here, we measure presynaptic calcium influx and EPSCs at a fast central synapse that displays prominent synaptic facilitation. The increases in calcium influx that we observe are much smaller than at the calyx of Held. In granule cell terminals, calcium influx increases only $\sim 15 \%$ during brief high-frequency stimulation. Such changes in calcium entry cannot account for the very large synaptic enhancement at parallel fiber synapses, especially in conditions of low release probability. 
Our experiments have important implications for the study of synapses during trains. We confirm that changes in fiber excitability are potentially a significant complication in such studies. Here, we needed to measure the presynaptic volley during trains to select fiber tracts where the presynaptic volley remained relatively constant throughout the train (see Materials and Methods). For other synapses this may not be possible.

We studied two modulators that were known to have large effects on calcium influx, and this mechanism turned out to be the primary means by which they affected transmission during trains. Although activation of $\mathrm{A}_{1}$ or $\mathrm{GABA}_{\mathrm{B}}$ receptors does not appear to differentially affect short-term plasticity at this synapse, we do not exclude the possibility that during trains, other modulators might have more diverse actions.

\section{REFERENCES}

Abbott LF, Sen K, Varela JA, Nelson SB (1997) Synaptic depression and cortical gain control. Science 275:220-222.

Atluri PP, Regehr WG (1996) Determinants of the time course of facilitation at the granule cell to Purkinje cell synapse. J Neurosci 16:5661-5671.

Atluri PP, Regehr WG (1998) Delayed release of neurotransmission from cerebellar granule cells. J Neurosci 18:8214-8227.

Augustine G (1990) Regulation of transmitter release at the squid giant synapse by presynaptic delayed rectifier potassium current. J Physiol (Lond) 431:343-364.

Bean BP (1989) Neurotransmitter inhibition of neuronal calcium currents by changes in channel voltage dependence. Nature 340:153-156.

Betz WJ (1970) Depression of transmitter release at the neuromuscular junction of the frog. J Physiol (Lond) 206:629-644.

Borst JG, Sakmann B (1998) Facilitation of presynaptic calcium currents in the rat brainstem. J Physiol 513:149-155.

Brenowitz S, David J, Trussell L (1998) Enhancement of synaptic efficacy by presynaptic $\mathrm{GABA}_{\mathrm{B}}$ receptors. Neuron 20:135-141.

Brody DL, Patil PG, Mulle JG, Snutch TP, Yue DT (1997) Bursts of action potential waveforms relieve G-protein inhibition of recombinant P/Q-type $\mathrm{Ca}^{2+}$ channels in HEK 293 cells. J Physiol (Lond) 499:637-644.

Buonomano DV, Merzenich MM (1995) Temporal information transformed into a spatial code by a neural network with realistic properties. Science 267:1028-1030.

Charlton MP, Bittner GD (1978) Presynaptic potentials and facilitation of transmitter release in the squid giant synapse. J Gen Physiol 72:487-511.

Charlton MP, Smith SJ, Zucker RS (1982) Role of presynaptic calcium ions and channels in synaptic facilitation and depression at the squid giant synapse. J Physiol (Lond) 323:173-193.

Cuttle MF, Tsujimoto T, Forsythe ID, Takahashi T (1998) Facilitation of the presynaptic calcium current at an auditory synapse in rat brainstem. J Physiol (Lond) 512:723-729.

Davies CH, Pozza MF, Collingridge GL (1993) CGP 55845A: a potent antagonist of $\mathrm{GABA}_{\mathrm{B}}$ receptors in the CA1 region of rat hippocampus. Neuropharmacology 32:1071-1073.

Del Castillo J, Katz B (1954) Statistical factors involved in neuromuscular facilitation and depression. J Physiol (Lond) 124:574-585.

Dittman JS, Regehr WG (1996) Contributions of calcium-dependent and calcium-independent mechanisms to presynaptic inhibition at a cerebellar synapse. J Neurosci 16:1623-1633.

Dittman JS, Regehr WG (1997) Mechanism and kinetics of heterosynaptic depression at a cerebellar synapse. J Neurosci 17:9048-9059.

Dittman JS, Regehr WG (1998) Calcium dependence and recovery kinetics of presynaptic depression at the climbing fiber to Purkinje cell synapse. J Neurosci 18:6147-6162.

Dobrunz LE, Stevens CF (1999) Response of hippocampal synapses to natural stimulus patterns. Neuron 22:157-166.

Dodge FA, Rahamimoff R (1967) Co-operative action of calcium ions in transmitter release at the neuromuscular junction. J Physiol (Lond) 193:419-432.

Dunlap K, Fischbach GD (1978) Neurotransmitters decrease the calcium component of sensory neurone action potentials. Nature 276:837-839.
Elmqvist D, Quastel DMJ (1965) A quantitative study of end-plate potentials in isolated human muscle. J Physiol (Lond) 178:505-529.

Elmslie KS, Zhou W, Jones SW (1990) LHRH and GTP-g-S modify calcium current activation in bullfrog sympathetic neurons. Neuron 5:75-80.

Feng TP (1941) Studies on the neuromuscular junction. Clin J Physiol 16:341-372.

Forsythe ID, Tsujimoto T, Barnes-Davies M, Cuttle MF, Takahashi T (1998) Inactivation of presynaptic calcium current contributes to synaptic depression at a fast central synapse. Neuron 20:797-807.

Galarreta M, Hestrin S (1998) Frequency-dependent synaptic depression and the balance of excitation and inhibition in the neocortex. Nat Neurosci 1:587-594.

Haleen SJ, Steffen RP, Hamilton HW (1987) PD 116,948, a highly selective A1 adenosine receptor antagonist. Life Sci 40:555-561.

Herlitze S, Garcia DE, Mackie K, Hille B, Scheuer T, Catterall WA (1996) Modulation of $\mathrm{Ca} 2+$ channels by G-protein beta gamma subunits. Nature 380:258-262.

Herrington J, Bookman RJ (1995) Pulse control V4.5: IGOR XOPs for patch clamp data acquisition. Miami, FL: University of Miami.

Ikeda SR (1996) Voltage-dependent modulation of N-type calcium channels by G-protein beta gamma subunits. Nature 380:255-258.

Isaacson JS, Solis JM, Nicoll RA (1993) Local and diffuse synaptic actions of GABA in the hippocampus. Neuron 10:165-175.

Ito M (1984) The cerebellum and neural control. New York: Raven.

Jane DE, Thomas NK, Tse HW, Watkins JC (1996) Potent antagonists at the L-AP4- and (1S,3S)-ACPD-sensitive presynaptic metabotropic glutamate receptors in the neonatal rat spinal cord. Neuropharmacology 35:1029-1035.

Kamiya H, Zucker RS (1994) Residual $\mathrm{Ca}^{2+}$ and short-term synaptic plasticity. Nature 371:603-606.

Katz B, Miledi R (1968) The role of calcium in neuromuscular facilitation. J Physiol (Lond) 195:481-492.

Klein M, Kandel ER (1980) Mechanism of calcium current modulation underlying presynaptic facilitation and behavioral sensitization in Aplysia. Proc Natl Acad Sci USA 77:6912-6916.

Kocsis JD, Malenka RC, Waxman SG (1983) Effects of extracellular potassium concentration on the excitability of the parallel fibres of the rat cerebellum. J Physiol (Lond) 334:225-244.

Konnerth A, Llano I, Armstrong CM (1990) Synaptic currents in cerebellar Purkinje cells. Proc Natl Acad Sci USA 87:2662-2665.

Liley AW, North KAK (1953) An electrical investigation of effects of repetitive stimulation on mammalian neuromuscular junction. J Neurophysiol 16:509-527.

Lisman JE (1997) Bursts as a unit of neural information: making unreliable synapses reliable. Trends Neurosci 20:38-43.

Llano I, Marty A, Armstrong CM, Konnerth A (1991) Synaptic- and agonist-induced excitatory currents of Purkinje cells in rat cerebellar slices. J Physiol (Lond) 434:183-213.

Magleby KL (1987) Short-term changes in synaptic efficacy. In: Synaptic function (Edelman GM, Gall WE, Cowan WM, eds), pp 21-56. New York: Wiley.

Manthei RC, Wricht DC, Kenny AD (1973) Altered CSF constituents and retrograde amnesia in rats: a biochemical approach. Physiol Behav $10: 517-521$.

Mintz IM, Sabatini BL, Regehr WG (1995) Calcium control of transmitter release at a cerebellar synapse. Neuron 15:675-688.

Palay SL, Chan-Palay V (1974) Cerebellar cortex. New York: Springer.

Pananceau M, Chen H, Gustafsson B (1998) Short-term facilitation evoked during brief afferent tetani is not altered by long-term potentiation in the guinea-pig hippocampal CA1 region. J Physiol (Lond) 508:503-514.

Patil PG, Brody DL, Yue DT (1998) Preferential closed-state inactivation of neuronal calcium channels. Neuron 20:1027-1038.

Qian SM, Delaney KR (1997) Neuromodulation of activity-dependent synaptic enhancement at crayfish neuromuscular junction. Brain Res 771:259-270.

Regehr WG, Atluri PP (1995) Calcium transients in cerebellar granule cell presynaptic terminals. Biophys J 68:2156-2170.

Regehr WG, Mintz IM (1994) Participation of multiple calcium channel types in transmission at single climbing fiber to Purkinje cell synapses. Neuron 12:605-613.

Regehr WG, Tank DW (1991) Selective fura-2 loading of presynaptic terminals and nerve cell processes by local perfusion in mammalian brain slice. J Neurosci Methods 37:111-119. 
Sabatini BL, Regehr WG (1997) Control of neurotransmitter release by presynaptic waveform at the granule cell to Purkinje cell synapse. J Neurosci 17:3425-3435.

Sabatini BL, Regehr WG (1998) Optical detection of presynaptic calcium currents. Biophys J 74:1549-1563.

Salin PA, Malenka RC, Nicoll RA (1996) Cyclic AMP mediates a presynaptic form of LTP at cerebellar parallel fiber synapses. Neuron 16:797-803.

Scanziani M, Salin PA, Vogt KE, Malenka RC, Nicoll RA (1997) Usedependent increases in glutamate concentration activate presynaptic metabotropic glutamate receptors. Nature 385:630-634.

Selig DK, Nicoll RA, Malenka RC (1999) Hippocampal long-term potentiation preserves the fidelity of postsynaptic responses to presynaptic bursts. J Neurosci 19:1236-1246.

Silver RA, Momiyama A, Cull-Candy SG (1998) Locus of frequencydependent depression identified with multiple-probability fluctuation analysis in rat climbing fibre-Purkinje cell synapses. J Physiol (Lond) 510:881-902.

Stanley EF (1986) Decline in calcium cooperativity as the basis of facilitation at the squid giant synapse. J Neurosci 6:782-789.

Stevens CF, Wesseling JF (1998) Activity-dependent modulation of the rate at which synaptic vesicles become available to undergo exocytosis. Neuron 21:415-424.

Takeuchi A (1958) The long-lasting depression in neuromuscular transmission of frog. Jpn J Physiol 12:102-113.

Trussell LO, Fischbach GD (1989) Glutamate receptor desensitization and its role in synaptic transmission. Neuron 3:209-218.
Trussell LO, Zhang S, Raman IM (1993) Desensitization of AMPA receptors upon multiquantal neurotransmitter release. Neuron 10:1185-1196.

Tsodyks MV, Markram H (1997) The neural code between neocortical pyramidal neurons depends on neurotransmitter release probability. Proc Natl Acad Sci USA 94:719-723.

Varela JA, Sen K, Gibson J, Fost J, Abbott LF, Nelson SB (1997) A quantitative description of short-term plasticity at excitatory synapses in layer 2/3 of rat primary visual cortex. J Neurosci 17:7926-7940.

Vyshedskiy A, Delaney KR, Lin J-W (1998) Neuromodulators enhance transmitter release by two separate mechanisms at the inhibitor of crayfish opener muscle. J Neurosci 18:5160-5169.

Wang L-Y, Kaczmarek LK (1998) High-frequency firing helps replenish the readily releasable pool of synaptic vesicles. Nature 394:384-388.

Wu LG, Saggau P (1997) Presynaptic inhibition of elicited neurotransmitter release. Trends Neurosci 20:204-212.

Yawo H, Chuhma N (1993) Preferential inhibition of $\omega$-conotoxinsensitive presynaptic $\mathrm{Ca}^{2+}$ channels by adenosine autoreceptors. Nature 365:256-258.

Zhao M, Hollingworth S, Baylor SM (1996) Properties of tri- and tetracarboxylate $\mathrm{Ca} 2+$ indicators in frog skeletal muscle fibers. Biophys $\mathrm{J}$ 70:896-916.

Zucker RS (1989) Short-term synaptic plasticity. Annu Rev Neurosci 12:13-31.

Zucker RS (1999) Calcium- and activity-dependent synaptic plasticity. Curr Opin Neurobiol 9:305-313. 